\title{
Biophysical characterization of Cav1.4 L-type calcium channel mutants causing congenital stationary night blindness type 2 in humans
}

\author{
Klaus W Schicker ${ }^{1 \dagger}$, Verena Burtscher ${ }^{1 \dagger}$, Dagmar Knoflach ${ }^{1}$, Anamika Singh ${ }^{2}$, Thomas Stockner ${ }^{1}$, \\ Alexandra Koschak ${ }^{1 *}$ \\ From 18th Scientific Symposium of the Austrian Pharmacological Society (APHAR). Joint meeting with the \\ Croatian, Serbian and Slovenian Pharmacological Societies. \\ Graz, Austria. 20-21 September 2012
}

\section{Background}

$\mathrm{Ca}_{V}$ 1.4 L-type calcium channels show unique biophysical properties such as slow inactivation due to the lack of calcium-dependent inactivation (CDI). These properties make $\mathrm{Ca}_{\mathrm{V}} 1.4$ channels appropriate candidates for triggering persistent glutamate release at retinal photoreceptor cell synapses. Mutations in the CACNA1F gene encoding for the $\mathrm{Ca}_{V} 1.4 \alpha 1$ subunit are described in patients with X-linked congenital stationary night blindness type 2 (CSNB2). Impaired transmission between rod photoreceptor cells and second-order neurons manifests as night blindness and various other visual symptoms in the affected individuals.

\section{Methods}

The aim of this study was to investigate the functional properties of $\mathrm{Ca}_{\mathrm{V}} 1.4$ mutants L849P and R1816stop compared to wild-type (WT) in transiently transfected tsA 201 cells $(+\beta 3,+\alpha 2 \delta-1)$ via whole-cell patch clamp technique using $15 \mathrm{mM} \mathrm{Ba}^{2+}$ and $\mathrm{Ca}^{2+}$ as charge carrier. For statistics, either Mann-Whitney (two groups) or Kruskal-Wallis test and Dunn's Post hoc test (multiple comparisons) were used.

\section{Results}

L849P was mainly characterized by a reduced current density (pA/pF: WT: $-16.3 \pm 1.6(\mathrm{n}=38)$, L849P: $-2.5 \pm 0.3$

\footnotetext{
* Correspondence: alexandra.koschak@meduniwien.ac.at

† Contributed equally

'Department of Neurophysiology and Neuropharmacology, Center for Physiology and Pharmacology, Medical University of Vienna, 1090 Vienna, Austria

Full list of author information is available at the end of the article
}

$(\mathrm{n}=12), \mathrm{p}<0.0001 ; \mathrm{Ca}^{2+}$ ), only minor, not significant ( $p>0.05$ ) changes in the voltage-dependent activation properties were observed. In presence of the dihydropyridin-activator BayK8644 $(5 \mu \mathrm{M})$ the current density was increased $\sim 10$-fold $(\mathrm{p}<0.001)$. The fold-increase in current density was comparable to WT. As expected R1816stop, which lacks an intrinsic C-terminal modulator (CTM), exhibited CDI (f-value: WT: $0.11 \pm 0.03(\mathrm{n}=8)$; R1816stop: $0.63 \pm 0.02(\mathrm{n}=22))$ and shifted the voltagedependence of activation to more negative voltages (V0.5 act in mV: WT: $1.8 \pm 0.3(\mathrm{n}=74)$, R1816stop: $-12.3 \pm 0.3(\mathrm{n}=23))$. In presence of the Ca $1.4-\mathrm{CTM}$; comprising the last $122 \mathrm{C}$-terminal residues WT conditions were fully restored, e.g. V0.5 act $2.2 \pm 1.0 \mathrm{mV}(\mathrm{n}=14)$ $(\mathrm{p}<0.0001)$.

\section{Conclusions}

We assume that the reduced current density observed in mutant L849P derives from decreased channel expression, which might be explained by a folding defect of the $\mathrm{Ca}_{V} 1.4$ channel protein rather than a reduced open probability. Moreover, the fact that the functional phenotype of the R1816stop can be rescued bears a potential pharmacotherapeutic concept based to the $\mathrm{C}$-terminal modulatory mechanism present in $\mathrm{Ca}_{\mathrm{V}} 1.4$ channels.

\section{Acknowledgements \\ Financial support was given by the Austrian Science Fund (FWF, grant P22526 to A.K.). \\ Author details \\ 'Department of Neurophysiology and Neuropharmacology, Center for Physiology and Pharmacology, Medical University of Vienna, 1090 Vienna,}


Austria. ${ }^{2}$ Department of Pharmacology and Toxicology, Institute of Pharmacy, University of Innsbruck, 6020 Innsbruck, Austria.

Published: 17 September 2012

doi:10.1186/2050-6511-13-S1-A69

Cite this article as: Schicker et al:: Biophysical characterization of $\mathrm{Ca}_{\mathrm{v}} 1.4$

L-type calcium channel mutants causing congenital stationary night

blindness type 2 in humans. BMC Pharmacology and Toxicology 2012

13(Suppl 1):A69.

Submit your next manuscript to BioMed Central and take full advantage of:

- Convenient online submission

- Thorough peer review

- No space constraints or color figure charges

- Immediate publication on acceptance

- Inclusion in PubMed, CAS, Scopus and Google Scholar

- Research which is freely available for redistribution

Submit your manuscript at www.biomedcentral.com/submit 